\title{
A szívüregek vizsgálata modern echokardiográfiás technikákkal
}

\author{
Kovács Attila1, Ágoston Gergely² \\ ${ }^{1}$ Semmelweis Egyetem, Városmajori Szív- és Érgyógyászati Klinika, Budapest \\ ${ }^{2}$ Szegedi Tudományegyetem, Általános Orvostudományi Kar, Családorvosi Intézet, Szeged
}

Levelezési cím:

Dr. Kovács Attila, e-mail: attila.kovacs@med.semmelweis-univ.hu

\begin{abstract}
A longitudinális strain mérése egy viszonylag új és megalapozott technika a bal pitvar vizsgálatában, valamint prognosztikus értékű számos kardiológiai kórképben. A bal pitvar funkciójáról kvantitatív adattal szolgál, így pontosabban leírhatók a strukturális eltérések, a fibrosis súlyossága vagy a bal pitvar merevségének mértéke. A jobb kamra esetében is nagyon hasonló hozzáadott értékröl beszélhetünk a longitudinális strain esetében, azonban a kamra komplex geometriája folytán a 3D-echokardiográfia használata még inkább felértékelődik. A bal kamrai globális logitudinális strain (GLS) alkalmas a szubklinikus balkamra-diszfunkció kimutatására akkor is, amikor az ejekciós frakció normál értéket mutat. Az elmúlt években egyre több adat jelent meg a GLS erős prognosztikus értékével kapcsolatban, ilyen kórállapotok az emelkedett bal kamrai töltőnyomás, a szívelégtelenség vagy a billentyübetegségek. A GLS-ből számított mechanikai diszperzió szintén ígéretes paraméter, a myocardium fibrosisának, hegesedésének korai indikátora lehet, így segítségével a kamrai ritmuszavarok szubsztrátja felismerhetővé válhat. Ugyanakkor meg kell jegyezni, hogy egy rendkívül pontos volumetrikus mérés és ejekciósfrakció-számítás 3D-echokardiográfia segítségével nemcsak diagnosztikus és prognosztikus haszonnal, hanem a különböző beavatkozások helyesebb indikációján keresztül egészséggazdasági haszonnal is járhat.
\end{abstract}

Kulcsszavak: szívüregek, deformáció-képalkotás, 3D-echokardiográfia

Modern (up-to-date) imaging techniques to evaluate cardiac chambers by transthoracic echocardiography Left atrial (LA) longitudinal strain is a novel parameter used for the evaluation of LA function with demonstrated prognostic value in several cardiac diseases. Its ability to quantify myocardial deformation accurately reflects the degree of structural alterations, myocardial fibrosis and chamber stiffness. The same benefits of longitudinal strain apply for the right ventricle as well. However, the complex geometry of the chamber often requires the use of 3D imaging. Left ventricular global longitudinal strain (GLS) detects subtle changes in myocardial function, often not quantifiable by left ventricular ejection fraction (LVEF) alone. It has been recently recognized that GLS has greater prognostic value than LVEF in several conditions like elevated LV filling pressure, heart failure and valvular heart diseases. The GLS derived parameter mechanical dispersion (MD) might indicate LV myocardial fibrosis, substrate for malignant arrhythmias. Of note, the highly accurate measurement of LV volumes and ejection fraction by 3D echocardiography may provide not just added diagnostic and prognostic value, but may be more cost-effective through the proper indication of specific cardiac therapies.

Keywords: cardiac chambers, deformation imaging, 3D echocardiography

A kézirat 2020. 03. 26-án érkezett a szerkesztőségbe, 2020. 04. 08-án került elfogadásra. 


\section{A bal és jobb pitvar vizsgálata modern echokardiográfiás technikákkal}

A szívciklus során a bal és jobb pitvar aktívan részt vesz a perctérfogat fenntartásában. A kamrák korai diasztolés szívó hatása előtt a rezervoár fázisban a pitvarok tágulnak, feszülnek, igyekeznek alkalmazkodni a telődés okozta térfogat- és nyomásterheléshez. A konduit fázis alkalmával, amikor mindkét atrioventrikuláris billentyű nyitva van, a kamrák telődése zajlik, majd a pitvarok aktív kontrakciójukkal segítik a kamrák telődését, és ez által a perctérfogat fenntartását. Az életkor előrehaladtával, már akár 40 éves kor felett a pitvarok aktív pumpafunkciója fokozódik. Mindezek a dinamikus és fázisosan ismétlődő pitvari müködések teszik optimálissá a pitvarok és kamrák telődését, ürülését és patológiás körülmények között kompenzáló mechanizmusokkal igyekeznek fenntartani az egyensúlyt.

A napi rutinban az echokardiográfiás vizsgálat során általában csak a bal pitvar átmérőjét, szerencsésebb esetben a térfogatát határozzuk meg a rendelkezésre álló 2D-módszerek segítségével. Lehetőségünk van azonban a pitvari volumenek 3D-szemiautomatikus mérésére is. A 3D-méréssel meghatározott bal pitvari volumenek szignifikánsan nagyobbak a 2D-méréshez viszonyítva, ezért a korábban meghatározott patológiás értékhatárok nem használhatóak, amennyiben 3D-mérést alkalmazunk. Ugyanakkor a 3D-technikával mért volumenek jobb egyezést mutatnak a szív-MR-rel meghatározott értékekkel, és reprodukálhatóságuk is jobb (1). A térfogatok (főként, ha EKG-kapuzással mérjük a maximális, minimális és a pitvari kontrakció előtti térfogatot) fontos, sok szempontból prediktív paraméterek, azonban nem adnak információt a pitvarban a szívciklus során történő, finom mechanikai változásokról (2). Ezzel szemben a speckle tracking alapú straintechnikával egy metszetből és szívciklusból meghatározható a pitvar rezervoár, konduit és aktív pumpafunkciója (1. ábra $A$ és $B$ panel) (3). Attól függően, hogy a szívciklus melyik pillanatától (referenciapont/nulla strain) végezzük a speckle tracking alapú strainanalízist, a pitvarok eltérő funkciójáról kapunk információt.

Amennyiben az analízist a diasztolé végétől (a mitrális billentyű záródásának időpontjában) indítjuk (ez a mitrális beáramlás A hullámának végére, EKG-n legtöbbször az $\mathrm{R}$ hullám csúcsára esik) a pitvar rezervoár (LASr, korábbi terminológiával PALS: peak atrial longitudinal strain) funkciójáról kapunk kvantitatív informáci-

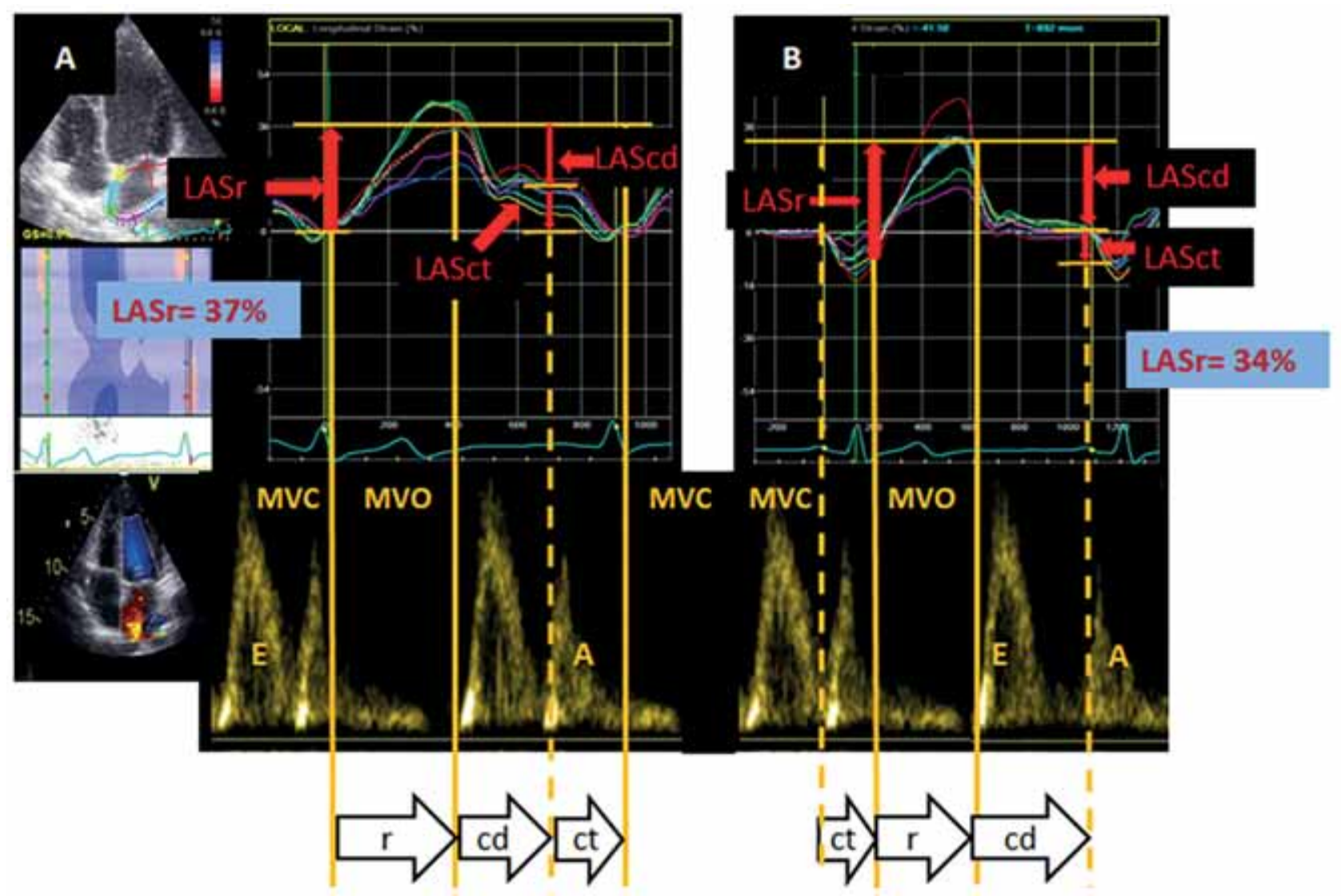

1. ÁBRA. A rezervoár, a konduit és a kontrakció fázisában rögzített pitvari longitudinális strainértékek. Az $A$ ÁBRÁN a referenciapont az A hullám vége (a diasztolé kezdete). A B ÁBRÁN a referenciapont a pitvari kontrakció kezdete (A hullám kezdete). LASr: Bal pitvari rezervoár strain, LASct: konduit funkciót jellemző strainérték, LAScd: a pitvari kontrakciós fázist jellemző strainérték, MVC: mitral valve closure, MVO: mitral valve opening, r: rezervoár, cd: konduit, ct: kontrakció. Látható, hogy a két metódus alkalmazásával eltérő rezervoár strainértéket kapunk. 
ót, amelynek értéke fiziológiásan átlagosan 39,4\% (3, 4). A pitvari kontrakció kezdetétől (mitrális beáramlás $A$ hullámának kezdete, EKG-n a $\mathrm{P}$ hullám kezdete) történő analízis során a pitvar konduit funkciójáról (LAScd) kapunk információt a pozitív kitérés abszolút értéke alapján, amelynek átlagos értéke egészséges egyéneknél $-23 \%$. Szintén ettől a referenciaponttól állapítható meg sinusritmus esetén a pitvari kontrakció által létrehozott negatív strainkitérés (LASct), amelynek átlagos referenciaértéke $-17,4 \%$. Mivel a konduit fázis és a kontrakció ideje alatt a pitvar fala rövidül, ezért a két értéket egységesen negatív számmal jelöljük. A két kapuzási módszerrel (eltérő referencia vagy „nulla” pont) eltérő straineredményeket kaphatunk, ezért a referenciapont feltüntetése a mérés során mindenképpen indokolt.

A gyakorlatban leggyakrabban a rezervoár funkciót jellemző, LASr strainértéket alkalmazzuk. Ez a legkönynyebben reprodukálható, sinusritmus és pitvarfibrilláció esetén is alkalmazható. Az aktuális konszenzusdokumentum is ennek a használatát javasolja, referenciapontként pedig a diasztolé végét tanácsos választani (3). Az LASr prognosztikus értékével áll rendelkezésre a legtöbb evidencia. Az LASr-érték szoros összefüggést mutat a pitvari fibrosis súlyosságával, az eredmény patohisztológiai feldolgozáson alapul (5). Az emelkedett töltőnyomás és a diasztolés diszfunkció súlyossági fokának becslésére is alkalmas a bal pitvari rezervoár strain (6). Singh és munkatársainak eredménye alapján a 20\% alatti LASr-érték magas bal kamrai töltőnyomásra utal (AUC: 0,76), vizsgálatukban az emelkedett töltőnyomást balszívfél-katéterezéssel, direkt nyomásméréssel támasztották alá (7). Megtartott ejekciós frakció mellett kialakult szívelégtelenségben (HFpEF), a dyspnoés panaszok megjelenésekor gyakran a bal pitvari strain az első paraméter, amely kóros értéket mutat, a szívelégtelenség-terápia hatására pedig a strainparaméterek javulása figyelhető meg (8). A bal pitvari rezervoár és kontrakciós strain értéke szoros összefüggést mutat az invazív módon mért éknyomással (nyugalomban és terhelésre egyaránt). $A \leq 33 \%$ rezervoár strainérték $88 \%$-os szenzitivitással és $77 \%$-os specificitással segített a HFpEF diagnózisában (9). Az LASr-érték hipertóniás betegekben a bal pitvar tágulata és a diasztolés diszfunkció kialakulása előtt jelzi a bal pitvar diszfunkcióját (10). Aszimptomatikus mitrális regurgitáció esetén a regurgitáció súlyosságát az LASr strainérték pontosabban tükrözi, mint a bal kamrai globális longitudinális strainérték (11).

Pitvarfibrillációban szintén számos értékes eredmény áll rendelkezésre a bal pitvari rezervoár funkciót leíró strainparaméterrel. Elektromos kardioverzió 6 hónapos utánkövetése során, a rezervoár funkció javulása a sinusritmus fennmaradása mellett szól (12). Az LASr főként abláció esetén rendelkezik erős prediktor értékkel. Régóta ismert tény, hogy a bal pitvari remodelling súlyossága (fibrosis mértéke) szorosan összefügg az abláció sikerességével (13). Ebből következik, hogy mivel az abláció előtti betegszelekció alapvető jelentőségü, ebben segíthet a bal pitvari strainanalízis is. Az abláció előtt mért LASr-érték független prediktora a bal pitvari reverz remodellingnek, amennyiben értéke az abláció előtt alacsony, a fibrosis annál kifejezettebb, és várhatóan az ablációt követően sem javul (14). Hasonlóan az elektromos kardioverziót követően megfigyelt jelenséghez, paroxizmális és perzisztens pitvarfibrilláció ablációja után, amennyiben a rezervoár strainértéke nem emelkedik szignifikánsan, rövid időn belül újabb pitvarfibrillációs epizód várható $(15,16)$. Kimutatták továbbá, hogy a bal pitvar aszimmetrikus alakja a pitvari volumentől és a diasztolés diszfunkció mértékétől független prediktora a pitvarfibrilláció rekurrenciájának (17). A fentieket összefoglalva, a bal pitvar fázikus funkciójának mérése speckle tracking technikával szenzitívebben jelezheti az adott folyamat progresszióját, illetve akár regresszióját, mint szimplán a pitvari térfogat mérése, mivel a reverz remodelling egy jóval lassabb, sokszor inkomplett folyamat (18).

Ugyan kevesebb irodalmi adat áll rendelkezésre, de a jobb pitvar esetében is kivitelezhető 3D volumetriás analízis, amelyre vonatkozóan a normálértékek is meghatározásra kerültek (19). A jobb pitvari strain prognosztikus értékével kapcsolatban azonban számos adat áll rendelkezésre. Pulmonalis hipertóniában a jobb pitvari rezervoár és konduit strainértéke csökkent, függetlenül a jobb pitvar nagyságától és a pitvari nyomásemelkedéstől, így megfelelően tükrözi a jobb kamrai nyomásterhelést és diszfunkciót (20). Primer pulmonalis hipertóniában a jobb pitvari longitudinális strain csúcsértéke, valamint a pitvari kontrakciót jellemző strain független prediktora a mortalitásnak és az alapbetegség progressziójából adódó hospitalizációnak (21). Szklerodermában szenvedő betegeknél a jobb pitvari strain szubklinikus diszfunkciója észlelhető nyugalomban és terhelés hatására kialakult pulmonalis nyomásemelkedéskor, akkor is, amikor a PAH diagnózisa még nem állítható fel (22). Szintén szklerodermában a jobb pitvar merevségének magasabb értéke (stiffness), amelyet a rezervoár strain és a jobb kamrai E/E' hányadosából számíthatunk, meghatározta a betegek funkcionális állapotát. A jobb pitvari rezervoár és konduit funkció ezekben a betegekben is szignifikánsan alacsonyabb volt a kontrollszemélyekhez viszonyítva (23).

\section{A jobb kamra vizsgálata modern echokardiográfiás technikákkal}

A jobb kamra morfológiájának és funkciójának megítélésében a modern technikáknak kitüntetett szerep juthat, hiszen összetett anatómiája és kétdimenziós echokardiográfiával való nehézkes vizsgálata miatt kevés szenzitív és/vagy prediktív hagyományos paraméterrel rendelkezünk (24). 
A 3D transztorakális echokardiográfia fejlődése új távlatokat nyitott a jobb kamra funkciójának megítélésében. Nem csupán az utóelemző szoftverek fejlődése, hanem a mind jobb térbeli és időbeli felbontással rendelkező transzducerek is nélkülözhetetlen részei ennek a folyamatnak. Legújabban már nincs szükség több szívciklusból való rekonstrukcióra, mivel az „élő” képnek is megfelelő az időbeli felbontása. Így tehát a technika még inkább gyorsult, nincs szükség a beteg légzésvisszatartására, és aritmia esetén is alkalmazható, mivel az összeillesztési (ún. stitch) mútermékek problémája nem merül fel. Egyre több gyártó rendelkezik saját, magán az ultrahanggépen is elérhető $3 D$ rekonstrukciós szoftverrel.

Egyre több adattal rendelkezünk a 3D-echokardiográfiával meghatározott jobb kamrai EF prognosztikus értékével kapcsolatban. Nochioka és munkatársai 1004 beteg felvételeit elemezték az ARIC-tanulmány részeként (25). Az ARIC egy nagy, átfogó epidemiológiai vizsgálat, amelynek keretében középkorú, illetve idősebb amerikaiakat vizsgáltak különböző modalitásokkal, majd természetesen utánkövetést is végeztek. Jelen tanulmány eredményei alapján a szívelégtelenségben a vizsgálatkor nem szenvedő páciensek esetén is a rosszabb jobb kamrai EF összefüggést mutatott a jövőbeli szívelégtelenség-eseményekkel és a mortalitással, függetlenül a bal kamrai EF, az NT-proBNP és a bal kamrai töltőnyomás értékeitől. Mindezen prognosztikus értékkel a hagyományos jobbkamra-funkciós paraméterek (fractional area change, s' szöveti Dopplerrel meghatározva) nem rendelkeztek. Hasonló, a bal kamrai EF-től független prognosztikus jelentőséget mutattak ki Surkova és munkatársai. Az olasz munkacsoport egy majd 400 főből álló, vegyes kardiális betegségekkel terhelt populációt vizsgált és követett átlagosan 3,7 évig (26). A balkamra-diszfunkciót $50 \%$, a jobbkamra-diszfunkciót $45 \%$ EF-érték alatt definiálták. A betegeket négy kategóriára osztották:
1. egyaránt megtartott bal- és jobbkamra-funkció,

2. csökkent bal-, de megtartott jobbkamra-funkció,

3. csökkent jobb-, de megtartott balkamra-funkció,

4. egyaránt csökkent bal- és jobbkamra-funkció.

A jobb kamrai EF összefüggést mutatott mind a kardiális okból bekövetkező, mind az összmortalitással, a csoportok túlélését vizsgálva pedig megállapították, hogy a csökkent jobbkamra-funkcióval, de megtartott balkamra-funkcióval rendelkező csoport hasonlóan rossz kimenetellel bír, mint az egyaránt csökkent balés jobbkamra-funkcióval rendelkező csoport. A hagyományos kétdimenziós paraméterek jelen tanulmányban sem bizonyultak prediktívnek. Továbbgondolva az eredményeiket meghatározták azokat a vágópontokat, amelyeket a kimenetel különbsége alapján a klinikumban is érdemes használni, és ezeket validálták is egy japán munkacsoport hasonló populációja segítségével (27). Mindezek alapján a $45 \%$ feletti jobb kamrai EF tekinthető normálisnak, míg a 40 és $45 \%$ között az enyhén, 30 és 40\% között a közepesen, míg 30\% alatt a súlyosan csökkent kategória különíthető el.

A jobb kamra szempontjából is érdekes populációt képviselnek az élsportolók, akiknél gyakran mérhetünk csökkent nyugalmi jobb kamrai EF-értéket. A kontrakció mintázata is megváltozik, a longitudinális rövidülés relatív jelentősége növekszik, míg a radiális, ún. fújtató effektus jelentősége csökken (28). Érdekes módon azonban ez az adaptív remodelling a globális funkció csökkenésével és a kontrakciós mintázat változásával független prediktora a spiroergometria során mért jobb aerob teljesítménynek (29). A modern 3D elemző technikák nem csupán a jobb kamra mozgásmintája, de komplex morfológiája alapján is új és jelentős (kór)élettani összefüggésekre világíthatnak rá (30). Lehetőség van immáron a jobb kamra regionális "görbületeinek" elemzésére is (2. ábra) (31).

A 2D speckle tracking esetében az első fontos kérdés rögtön a megfelelő nézet kiválasztása. Lang professzor

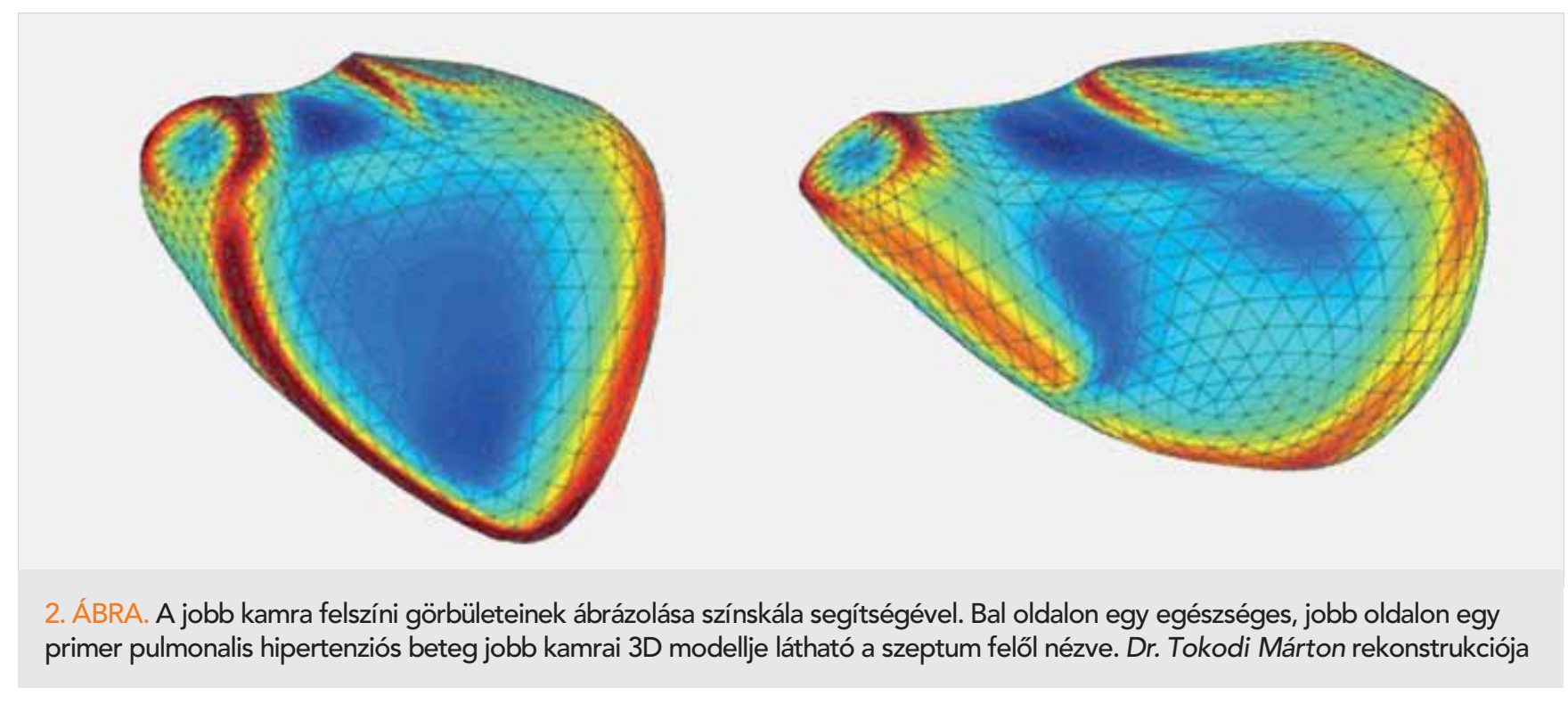


kutatócsoportja megállapította, hogy a klasszikus apikális négyüregi- és a jobb kamrára fókuszált nézetek egymással nem felcserélhetők: utóbbi esetén a lineáris átmérők konzekvensen nagyobbak, sőt a speckle tracking technikával mért szabad fali, illetve globális longitudinális strain is jobb funkcióra utal (az értékek negatívabbak). Mind a morfológiai, mind a funkcionális paraméterek reprodukálhatósága konzekvensen jobb volt a jobb kamrára fókuszált nézet esetén (32).

A speckle tracking technikával mért jobb kamrai szegmentális és globális longitudinális strain a bal kamrához hasonlóan jelentős hozzáadott értékkel rendelkezik a szisztolés vagy akár a diasztolés diszfunkció kimutatásában (33). Egy olasz munkacsoport 200, csökkent ejekciós frakciójú szívelégtelenségben szenvedő, azonban megtartott (>16 mm) TAPSE-vel rendelkező beteget vizsgált és követett átlagosan több mint két évig. A jobb kamra szabad fali longitudinális strain független prediktora volt a mortalitást vagy szívelégtelenség miatti hospitalizációt magában foglaló elsődleges végpontnak (34). Ugyanezen munkacsoport azt a fontos kérdést is vizsgálta ugyanezen a mintán, hogy vajon a szeptumot is magában foglaló globális, vagy csupán a szabadfali longitudinális straint érdemes-e inkább mérni. Eredményeik alapján mindkettőnek van prognosztikus értéke, azonban mivel a bal kamrai diszfunkció kevésbé befolyásolja, ezért a szabad fali mérés tünik célszerübbnek (35). Ugyanakkor arra is van adat, hogy a reprodukálhatóság szempontjából a globális mérés a kedvezőbb, de mindenesetre az bizonyosan kijelenthető, hogy a kétféle módszer közé egyenlőségjelet tenni hiba (36).

\section{Újdonságok a bal kamra 3D képallkotása területén}

A 3D-echokardiográfia tekintetében is természetesen a bal kamra kvantifikációja a legkiforrottabb a klinikai felhasználás szempontjából. Legújabban már nemcsak szemiautomatikus (néhány anatómiai referenciapont kézi kijelölését igénylö), hanem teljesen automatikus szoftveres megoldások is rendelkezésünkre állnak a bal kamrai endokardiális felszín felismerésére és követésére (3. ábra). Egy metaanalízis eredményei alapján a 3D-echokardiográfiás kvantifikáció kismértékben, de továbbra is alulbecsüli a bal kamrai volumeneket a goldstandard szív-MR-hez viszonyítva, ugyanakkor az ejekciós frakció (EF) tekintetében gyakorlatilag nincs különbség (37). Érdekesség, hogy a szemiautomata és

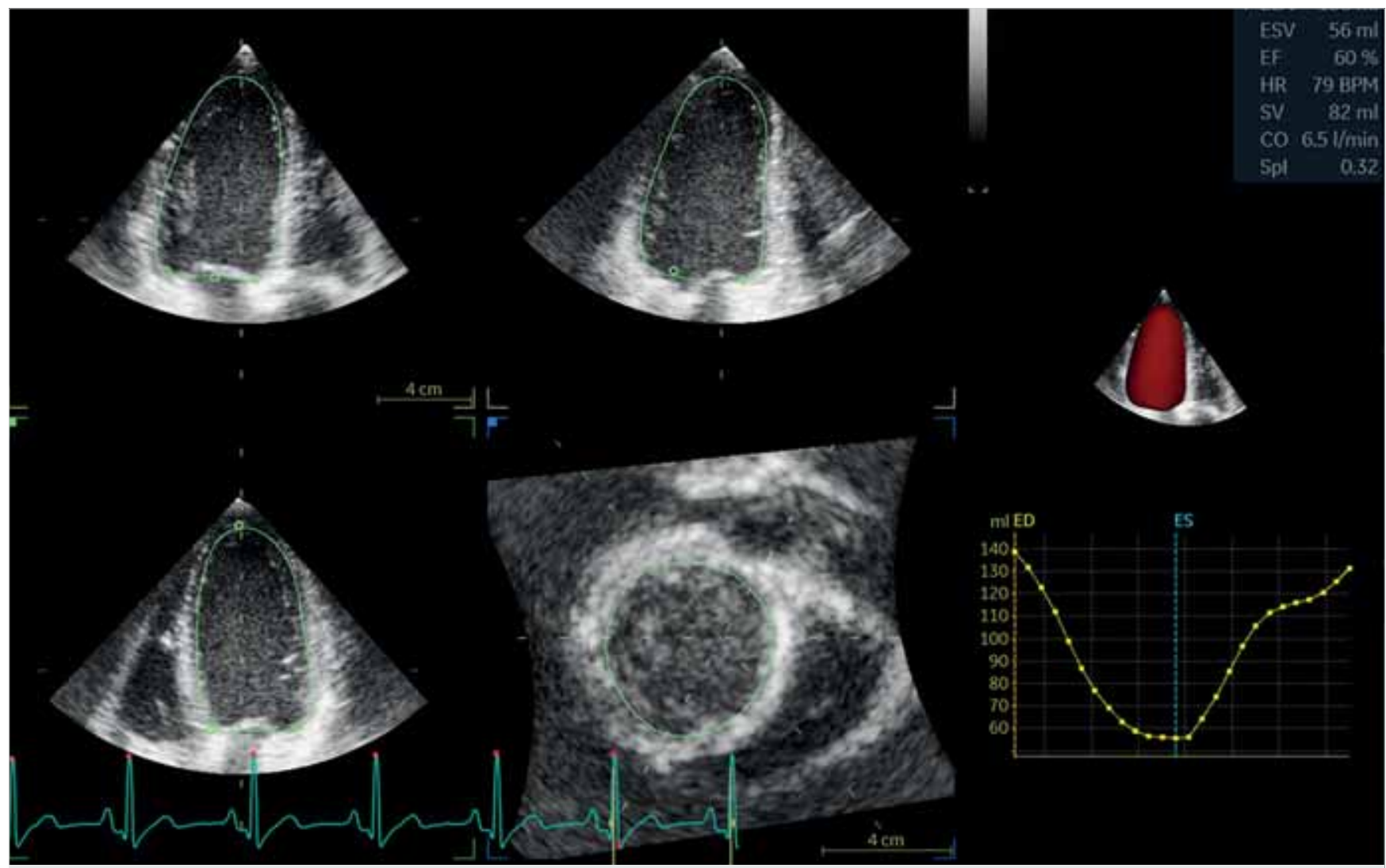

3. ÁBRA. A bal kamra 3D kvantifikációja. A szoftvertől függően lehetőség van szemiautomatikus, illetve teljesen automatikus endokardiális kontúrozásra. Ezután az algoritmus követni fogja a felszínt a rendelkezésre álló képkockákon, így a volumetriás értékek a szívciklus egésze során rendelkezésre állnak (ld. idő-volumen görbe a kép jobb alsó sarkában), és egy mozgó háromdimenziós bal kamrai modell is rekonstrukcióra kerül. A kulcsparaméterek (végdiasztolés volumen: EDV, végszisztolés volumen: ESV, ejekciós frakció: EF, verővolumen: SV, perctérfogat: CO, szfericitás index: Spl) automatikusan kiszámításra kerülnek. 
a teljesen automata szoftveres megoldások közül az utóbbiak által generált eredmények bizonyultak pontosabbnak és jobban reprodukálhatónak. Felmerülhet a kérdés, hogy miért is fontos az ilyen mértékü pontosság ezekben a mérésekben. Egy olasz munkacsoport 172 balkamra-diszfunkcióval (döntően iszkémiás etiológiával) rendelkező beteget vizsgált. Eredményeik alapján a 3D-echokardiográfiával meghatározott bal kamrai EF az esetek $20 \%$-ában változtatta volna meg az implantálható kardioverter defibrillátor indikációját (38). A medián 56 hónapos utánkövetés során a betegek 30\%-ában jelentkeztek major ritmuszavarok, amelyek fellépésének egyetlen független prediktora a 3D-echokardiográfiával meghatározott EF volt. Jelen tanulmány kiváló példa arra, hogy a pontosabb mérések nem csupán diagnosztikus és prognosztikus haszonnal, hanem egyben akár nagyobb költséghatékonysággal is járhatnak.

\section{Újdonságok a bal kamrai globális longitudinális strain terưletén}

A bal kamrai globális longitudinális strain számos kórképben rendelkezik diagnosztikus értékkel, és segít a diagnózis felállításában (39). Az elmúlt években a kuta- tás fő irányvonalát elsősorban a bal kamrai GLS prognosztikus értékének megállapítása jelentette. Heveny szívelégtelenségben a GLS jelentősebb prognosztikus értékkel bír, mint az ejekciós frakció. Park és munkatársai 4172 akut szívelégtelen beteget vontak be vizsgálatukba, ahol a beteg kórházi felvételekor mért GLS és ejekciós frakció hatását vizsgálták a túlélésre. Az 5 éves utánkövetés során a károsodott GLS magasabb mortalitással járt, minden 1\%-os GLS-csökkenés 5\%os mortalitásemelkedést jelentett (40). Nem találtak összefüggést az ejekciós frakció és a mortalitás között. Lassen és munkatársai a Copenhagen City Heart Study 6238 egyénének adatait dolgozták fel. A kombinált végpontok (kardiovaszkuláris halálozás, szívelégtelenség miatti hospitalizáció, miokardiális infarktus) tekintetében a 11 éves utánkövetés során a koradiasztolés longitudinális strainből számolt E/E' érték szoros öszszefüggést mutatott a végpontokkal, míg a hagyományos E/E' nem bizonyult prognosztikusnak (41). A miokardiális fibrosis az életkor előrehaladtával progrediál, és a jelenség összefüggésben áll az emelkedett töltőnyomással. A miokardiális fibrosis kihat az ingerületvezetésre és a kontraktilitásra, ezt a hatást jellemezhetjük a mechanikai diszperzióval (MD). Az MD a bal kamra 17 szegmentumában a longitudinális strain csúcsáig eltelt

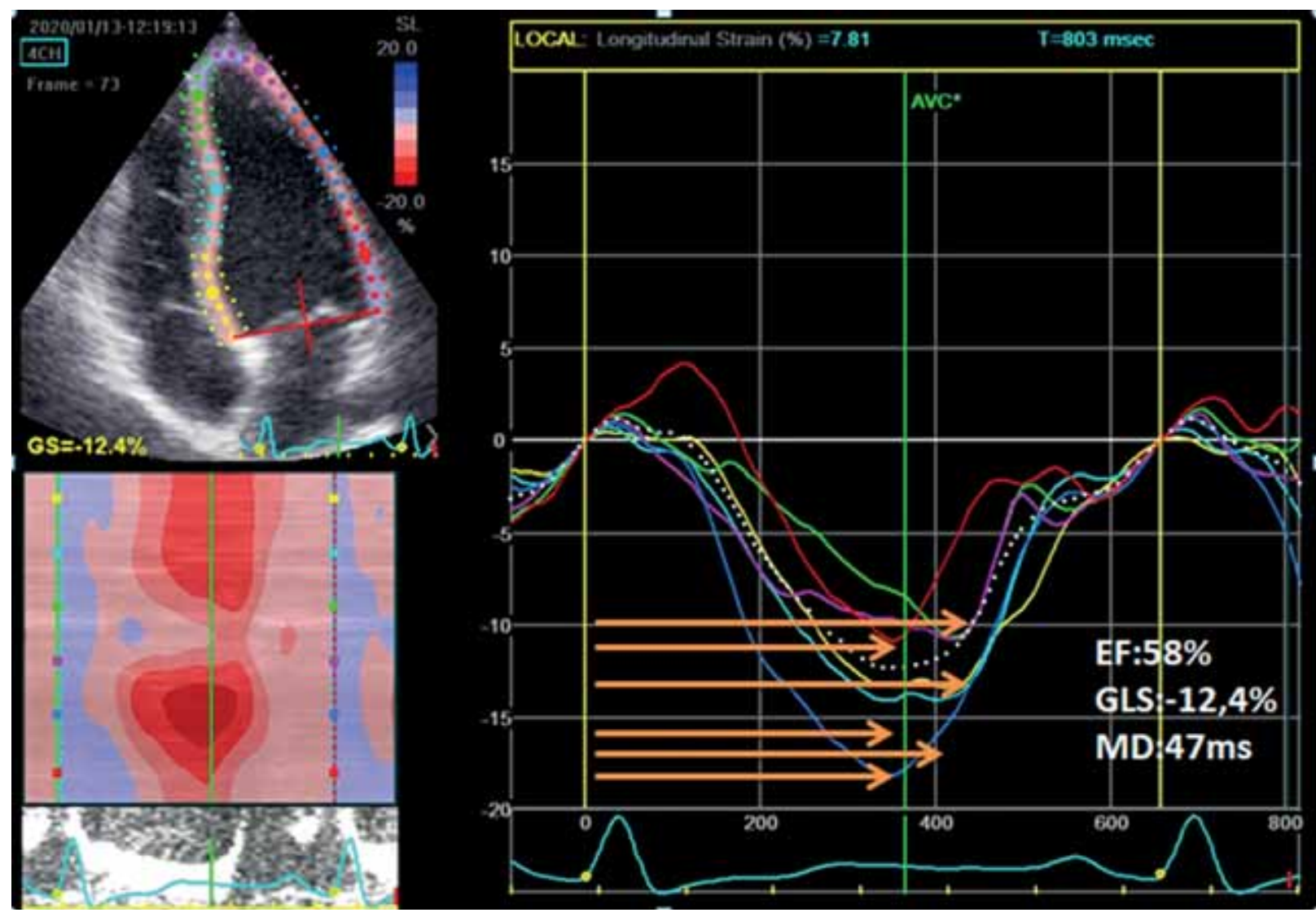

4. ÁBRA. A mechanikai diszperzió számítása. A Q hullám kezdetétől a straingörbe csúcsáig eltelt időt mérjük, a jelen esetben 6 szegmentumban. Majd a milliszekundumban kapott érték standard deviációját számoljuk (jelen esetben 47 ms). A straingörbe csúcsa az adott szegmentum maximális kontrakcióját jelenti 
idő standard deviációját jelenti (4. ábra). Modin és munkatársai az MD átlagos értékeit állapították meg több mint ezer beteg esetében. Az MD átlagértéke a populációban $45 \pm 38$ ms-nak bizonyult, és minden 10 ms-os MD-növekedés lineáris összefüggést mutatott a kardiovaszkuláris halálozással (42). Csökkent ejekciós frakciójú betegekben (EF $\leq 45 \%$ ) az MD a kamrai ritmuszavarok és a hirtelen szívhalál tekintetében prediktív értékü, míg a GLS vagy az ejekciós frakció nem mutatott ilyen prognosztikus jelentőséget (43). Az MD a későbbiekben akár segíthet a primer, profilaktikus ICD-beültetés indikációjának finomításában. A billentyübetegségek területén szintén meghatározó a GLS értéke, például tünetmentes, súlyos aortastenosisban az ejekciós frakciónál szenzitívebb, és korábban jelzi a bal kamrai diszfunkciót. A -18,2\%-nál rosszabb GLS-érték az utánkövetés során korábban és gyakrabban jelentkező panaszokkal és gyakoribb billentyücserével járt együtt, mint a -18,2\%-nál jobb GLS (44).

A 3D speckle tracking echokardiográfia esetében is rendelkezünk már a normálértékeket meghatározni igyekvő metaanalízissel (45). Ugyanakkor meg kell jegyezni, hogy jelenleg még az aktuálisan alkalmazott 3D speckle tracking szoftver alapján érdemes definiálni a kórosság határát, univerzális normálértékekről nem beszélhetünk. Mindazonáltal a globális longitudinális és globális area strainek viszonylag jó egyezést mutatnak a különböző szoftvergyártók termékei között. Egyre több adattal rendelkezünk a 3D speckle tracking hozzáadott prognosztikus értékéről is, akár a 2D globális longitudinális strainen felül is (46).

\section{Következtetések}

A bal pitvari deformáció analízise a hagyományos echokardiográfiás technikáknál szenzitívebb, független és additív prognosztikai jelentőséggel bír. Segítségével a pitvari funkció finom eltérései is leírhatóak, amellyel korábban, a pitvar tágulásának megjelenése előtt diagnosztizálható már a pitvar diszfunkciója. A jobb kamrai longitudinális strain és a 3D-echokardiográfiával meghatározott volumenek és ejekciós frakció a bal kamrától független, hozzáadott prognosztikus értékkel bírnak számos kórkép esetén, sőt akár tünetmentes egyénekben is. A bal kamrai GLS szintén prognosztikus jelentőséggel bír számos kardiovaszkuláris betegségben, és egyre több adatunk van arra, hogy az ejekciós frakciónál megbízhatóbb paraméter. Ugyanakkor az is jól látható, hogy ha megfelelő, nagy pontosságú, 3D-technikával mérjük a hagyományos 2D-mérésekkel szemben, akkor az ejekciós frakció is szenzitívebb. A szívüregek deformációs és 3D-analízise tanulási periódust igényel, és megalapozott standardok mentén szükséges a méréseket végezni. A technikák egyre szélesebb körben elérhetőek, egyre több kardiovaszkuláris kórképben alkalmazzuk őket, a mérések pedig egyre egyszerübben kivitelezhetőek és jól reprodukálhatóak, így várhatóan a klinikai gyakorlatban is jól használható, megalapozott és nagy jelentőségű módszerek lesznek.

\section{Nyilatkozat}

A szerzők kijelentik, hogy az összefoglaló közlemény megírásával kapcsolatban nem áll fenn velük szemben pénzügyi vagy egyéb lényeges összeütközés, összeférhetetlenségi ok, amelyek befolyásolhatják a közleményben bemutatott eredményeket, az abból levont következtetéseket vagy azok értelmezését.

\section{Irodalom}

1. Badano LP, Miglioranza MH, Mihaila S, et al. Left Atrial Volumes and Function by Three-Dimensional Echocardiography: Reference Values, Accuracy, Reproducibility, and Comparison With Two-Dimensional Echocardiographic Measurements. Circulation Cardiovasc Imaging 2016; 9(7). doi: 10.1161/CIRCIMAGING.115.004229.

2. Tadic M. The right atrium, a forgotten cardiac chamber: An updated review of multimodality imaging. Journal of Clinical Ultrasound:2015; 43(6): 335-345. doi: 10.1002/jcu.22261.

3. Badano LP, Kolias TJ, Muraru D, et al. Standardization of left atrial, right ventricular, and right atrial deformation imaging using two-dimensional speckle tracking echocardiography: a consensus document of the EACVI/ASE/Industry Task Force to standardize deformation imaging. European Heart Journal Cardiovascular Imaging 2018; 19(6): 591-600. doi: 10.1093/ehjci/jey042.

4. Pathan F, D'Elia N, Nolan MT, Marwick TH, Negishi K. Normal Ranges of Left Atrial Strain by Speckle-Tracking Echocardiography: A Systematic Review and Meta-Analysis. Journal of the American Society of Echocardiography: official publication of the American Society of Echocardiography 2017; 30(1): 59-70 e58. doi: 10.1016/j. echo.2016.09.007.

5. Cameli M, Lisi M, Righini FM, et al. Usefulness of atrial deformation analysis to predict left atrial fibrosis and endocardial thickness in patients undergoing mitral valve operations for severe mitral regurgitation secondary to mitral valve prolapse. The American Journal of Cardiology 2013; 111(4): 595-601. doi: 10.1016/j.amjcard.2012.10.049.

6. Singh A, Addetia K, Maffessanti F, Mor-Avi V, Lang RM. LA Strain for Categorization of LV Diastolic Dysfunction. JACC Cardiovascular Imaging 2017; 10(7): 735-743. doi: 10.1016/j.jcmg.2016.08.014.

7. Singh A, Medvedofsky D, Mediratta A, et al. Peak left atrial strain as a single measure for the non-invasive assessment of left ventricular filling pressures. The International Journal of Cardiovascular Imaging 2019; 35(1): 23-32. doi: 10.1007/s10554-018-1425-y.

8. Sanchis L, Gabrielli L, Andrea R, et al. Left atrial dysfunction relates to symptom onset in patients with heart failure and preserved left ventricular ejection fraction. European Heart Journal Cardiovascular Imaging 2015; 16(1): 62-67. doi: 10.1093/ehjci/jeu165.

9. Telles F, Nanayakkara S, Evans S, et al. Impaired left atrial strain predicts abnormal exercise haemodynamics in heart failure with preserved ejection fraction. European Journal of Heart Failure 2019; 21(4): 495-505. doi: 10.1002/ejhf.1399.

10. Cameli M, Ciccone MM, Maiello M, et al. Speckle tracking analysis: a new tool for left atrial function analysis in systemic hypertension: an overview. Journal of Cardiovascular Medicine 2016; 17(5): 339-343. doi: 10.2459/JCM.0000000000000073.

11. Cameli M, Mandoli GE, Nistor D, et al. Left heart longitudinal deformation analysis in mitral regurgitation. The International Journal of Cardiovascular Imaging 2018; 34(11): 1741-1751. doi: 10.1007/ s10554-018-1391-4.

12. Shaikh AY, Maan A, Khan UA, et al. Speckle echocardiographic left atrial strain and stiffness index as predictors of maintenance of sinus rhythm after cardioversion for atrial fibrillation: a prospective study. Cardiovascular Ultrasound 2012; 10: 48. doi: 10.1186/1476$7120-10-48$

13. Oakes RS, Badger TJ, Kholmovski EG, et al. Detection and quantification of left atrial structural remodeling with delayed-enhancement magnetic resonance imaging in patients with atrial fibrillation. Circulation 2009; 119(13): 1758-1767. doi: 10.1161/CIRCULATIONA- 
HA.108.811877.

14. Tops LF, Delgado V, Bertini $M$, et al. Left atrial strain predicts reverse remodeling after catheter ablation for atrial fibrillation. Journal of the American College of Cardiology 2011; 57(3): 324-331. doi: 10.1016/j.jacc.2010.05.063.

15. Motoki H, Negishi K, Kusunose K, et al. Global left atrial strain in the prediction of sinus rhythm maintenance after catheter ablation for atrial fibrillation. Journal of the American Society of Echocardiography: official publication of the American Society of Echocardiography. 2014; 27(11): 1184-1192. doi: 10.1016/j.echo.2014.08.017.

16. Sarvari SI, Haugaa KH, Stokke TM, et al. Strain echocardiographic assessment of left atrial function predicts recurrence of atrial fibrillation. European Heart Journal Cardiovascular Imaging 2016; 17(6): 660-667. doi: 10.1093/ehjci/jev185.

17. Nedios S, Koutalas E, Sommer P, et al. Asymmetrical left atrial remodelling in atrial fibrillation: relation with diastolic dysfunction and long-term ablation outcomes. Europace 2017; 19(9): 1463-1469. doi: 10.1093/europace/euw225.

18. Thomas L, Marwick TH, Popescu BA, Donal E, Badano LP. Left Atrial Structure and Function, and Left Ventricular Diastolic Dysfunction: JACC State-of-the-Art Review. Journal of the American College of Cardiology 2019; 73(15): 1961-1977. doi: 10.1016/j.jacc.2019.01.059. 19. Peluso D, Badano LP, Muraru D, et al. Right atrial size and function assessed with three-dimensional and speckle-tracking echocardiography in 200 healthy volunteers. European Heart Journal Cardiovascular Imaging 2013; 14(11): 1106-1114. doi: 10.1093/ehjci/jet024.

20. Querejeta Roca G, Campbell P, Claggett B, Solomon SD, Shah AM. Right Atrial Function in Pulmonary Arterial Hypertension. Circulation. Cardiovascular Imaging 2015; 8(11): e003521; discussion e003521. doi: 10.1161/CIRCIMAGING.115.003521.

21. Alenezi F, Mandawat A, II'Giovine ZJ, et al. Clinical Utility and Prognostic Value of Right Atrial Function in Pulmonary Hypertension. Circulation Cardiovascular Imaging 2018; 11(11): e006984. doi: 10.1161/CIRCIMAGING.117.006984.

22. D'Andrea A, D'Alto $M$, Di Maio $M$, et al. Right atrial morphology and function in patients with systemic sclerosis compared to healthy controls: a two-dimensional strain study. Clinical Rheumatology. 2016; 35(7): 1733-1742. doi: 10.1007/s10067-016-3279-9.

23. Nogradi A, Porpaczy A, Porcsa L, et al. Relation of Right Atrial Mechanics to Functional Capacity in Patients With Systemic Sclerosis. The American Journal of Cardiology 2018; 122(7): 1249-1254. doi: 10.1016/j.amjcard.2018.06.021.

24. Kovacs A, Lakatos B, Tokodi M, Merkely B. Right ventricular mechanical pattern in health and disease: beyond longitudinal shortening. Heart Failure Reviews 2019; 24(4): 511-520. doi: 10.1007/s10741019-09778-1.

25. Nochioka K, Querejeta Roca G, Claggett B, et al. Right Ventricular Function, Right Ventricular-Pulmonary Artery Coupling, and Heart Failure Risk in 4 US Communities: The Atherosclerosis Risk in Communities (ARIC) Study. JAMA Cardiology 2018; 3(10): 939-948. doi: 10.1001/jamacardio.2018.2454.

26. Surkova E, Muraru D, Genovese D, Aruta P, Palermo C, Badano LP. Relative Prognostic Importance of Left and Right Ventricular Ejection Fraction in Patients With Cardiac Diseases. Journal of American Society Echocardiography 2019; 32(11): 1407-1415 e1403. doi: 10.1016/j.echo.2019.06.009.

27. Muraru D, Badano LP, Nagata Y, et al. Development and prognostic validation of partition values to grade right ventricular dysfunction severity using 3D echocardiography. European Heart Journal Cardiovasc Imaging 2020; 21(1): 10-21. doi: 10.1093/ehjci/jez233.

28. Lakatos BK, Kiss O, Tokodi $M$, et al. Exercise-induced shift in right ventricular contraction pattern: novel marker of athlete's heart? American Journal of Physiology Heart Circulation Physiology 2018; 315(6): H1640-H1648. doi: 10.1152/ajpheart.00304.2018.

29. Lakatos BK, Molnar AA, Kiss O, et al. Relationship between Cardiac Remodeling and Exercise Capacity in Elite Athletes: Incremental Value of Left Atrial Morphology and Function Assessed by ThreeDimensional Echocardiography. Journal of the American Society of Echocardiography: official publication of the American Society of Echocardiography. 2019doi: 10.1016/j.echo.2019.07.017.

30. Lakatos BK, Tokodi M, Assabiny A, et al. Dominance of free wall radial motion in global right ventricular function of heart transplant recipients. Clinical Transplant 2018; 32(3): e13192. doi: 10.1111/ctr.13192. 31. Addetia K, Maffessanti F, Muraru D, et al. Morphologic Analy- sis of the Normal Right Ventricle Using Three-Dimensional Echocardiography-Derived Curvature Indices. Journal of the American Society of Echocardiography 2018; 31(5): 614-623. doi: 10.1016/j. echo.2017.12.009.

32. Genovese D, Mor-Avi V, Palermo C, et al. Comparison Between Four-Chamber and Right Ventricular-Focused Views for the Quantitative Evaluation of Right Ventricular Size and Function. Journal of American Society of Echocardiography 2019; 32(4): 484-494. doi: 10.1016/j.echo.2018.11.014.

33. Matyas C, Kovacs A, Nemeth BT, et al. Comparison of speckletracking echocardiography with invasive hemodynamics for the detection of characteristic cardiac dysfunction in type-1 and type-2 diabetic rat models. Cardiovascular Diabetology 2018; 17(1): 13. doi: 10.1186/ s12933-017-0645-0.

34. Carluccio E, Biagioli P, Alunni G, et al. Prognostic Value of Right Ventricular Dysfunction in Heart Failure With Reduced Ejection Fraction: Superiority of Longitudinal Strain Over Tricuspid Annular Plane Systolic Excursion. Circulation Cardiovascular Imaging 2018; 11(1): e006894. doi: 10.1161/CIRCIMAGING.117.006894.

35. Carluccio E, Biagioli $P$, Lauciello $R$, et al. Superior Prognostic Value of Right Ventricular Free Wall Compared to Global Longitudinal Strain in Patients With Heart Failure. Journal of American Society of Echocardiography 2019; 32(7): 836-844 e831. doi: 10.1016/j. echo.2019.02.011.

36. Sanz-de la Garza M, Giraldeau G, Marin J, et al. Should the septum be included in the assessment of right ventricular longitudinal strain? An ultrasound two-dimensional speckle-tracking stress study. International Journal of Cardiovasc Imaging 2019; 35(10): 1853-1860. doi: 10.1007/s10554-019-01633-6.

37. Kitano T, Nabeshima Y, Otsuji Y, Negishi K, Takeuchi M. Accuracy of Left Ventricular Volumes and Ejection Fraction Measurements by Contemporary Three-Dimensional Echocardiography with Semi- and Fully Automated Software: Systematic Review and Meta-Analysis of 1,881 Subjects. Journal of American Society of Echocardiography 2019; 32(9): 1105-1115 e1105. doi: 10.1016/j.echo.2019.04.417.

38. Rodriguez-Zanella H, Muraru D, Secco E, et al. Added Value of 3-Versus 2-Dimensional Echocardiography Left Ventricular Ejection Fraction to Predict Arrhythmic Risk in Patients With Left Ventricular Dysfunction. JACC Cardiovasc Imaging 2019; 12(10): 1917-1926. doi: 10.1016/j.jcmg.2018.07.011.

39. Kovács Attila ÁG. Speckle-tracking echocardiography in clinical practice. Cardiologia Hungarica. 2018; 1(48.1): 58. doi: DOI:10.26430/ CHUNGARICA 2018.48.1.58.

40. Park JJ, Park JB, Park JH, Cho GY. Global Longitudinal Strain to Predict Mortality in Patients With Acute Heart Failure. Journal of the American College of Cardiology 2018; 71(18): 1947-1957. doi: 10.1016/j.jacc.2018.02.064.

41. Lassen MCH, Biering-Sorensen SR, Olsen FJ, et al. Ratio of transmitral early filling velocity to early diastolic strain rate predicts longterm risk of cardiovascular morbidity and mortality in the general population. European Heart Journal 2019; 40(6): 518-525. doi: 10.1093/ eurheartj/ehy164.

42. Modin D, Biering-Sorensen SR, Mogelvang R, Jensen JS, Biering-Sorensen T. Prognostic Importance of Left Ventricular Mechanical Dyssynchrony in Predicting Cardiovascular Death in the General Population. Circulation; Cardiovascular Imaging 2018; 11(10): e007528. doi: 10.1161/CIRCIMAGING.117.007528.

43. Perry R, Patil S, Marx C, et al. Advanced Echocardiographic Imaging for Prediction of SCD in Moderate and Severe LV Systolic Function. JACC; Cardiovascular Imaging 2019doi: 10.1016/j.jcmg.2019.07.026. 44. Vollema EM, Sugimoto $T$, Shen $M$, et al. Association of Left Ventricular Global Longitudinal Strain With Asymptomatic Severe Aortic Stenosis: Natural Course and Prognostic Value. JAMA cardiology 2018; 3(9): 839-847. doi: 10.1001/jamacardio.2018.2288.

45. Truong VT, Phan HT, Pham KNP, et al. Normal Ranges of Left Ventricular Strain by Three-Dimensional Speckle-Tracking Echocardiography in Adults: A Systematic Review and Meta-Analysis. Journal of American Society of Echocardiography 2019; 32(12): 1586-1597 e1585. doi: 10.1016/j.echo.2019.07.012.

46. Coutinho Cruz M, Moura Branco L, Portugal G, et al. Three-dimensional speckle-tracking echocardiography for the global and regional assessments of left ventricle myocardial deformation in breast cancer patients treated with anthracyclines. Clinical Research in Cardiology 2019doi: 10.1007/s00392-019-01556-1 